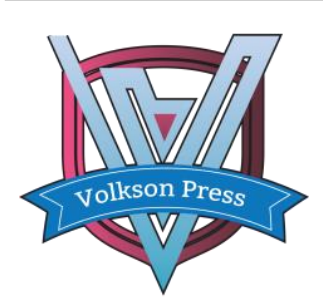

\author{
Contents List available at VOLKSON PRESS \\ Economics \& Management Innovations(EMI) \\ DOI : http://doi.org/10.26480/icemi.01.2017.307.308
}

\title{
The Motivation of Implementation of Enterprise Architecture for Government Organization
}

\author{
Worapat Paireekreng, ${ }^{1, *}$ and Chavanit Supasak ${ }^{1, *}$ \\ ${ }^{1}$ Dhurakij Pundit University, Bangkok, Thailand \\ *\{worapat.png,chavanit.sup\}@dpu.ac.th \\ This is an open access article distributed under the Creative Commons Attribution License, which permits unrestricted use, distribution, and reproduction in any \\ medium, provided the original work is properly cited.
}

\section{ARTICLE DETAILS}

\section{Article History:}

Received 02 october 2017

Accepted 06 october 2017

Available online 11 october 2017

Keywords:

Enterprise

Government

Implementation.

\section{ABSTRACT}

The implementation of information technology has been increasing significantly. Many organizations especially government confront the problem of unplanned and irrelevant information technology projects implementation. Thus, the Enterprise Architecture is needed to serve the organization's purposes. However, most of the framework did not cover government organization's factors and different missions of the organization. This research conducts the in-depth interview with experts and executives in the government organizations in order to identify the motivation and related factors to implement Enterprise Architecture for government organization. The summary of opinions from expert can be seen that management support and providing knowledge to organization seems to be important factors. The indicators to measure the success are also investigated in terms of financial process and goals.

\section{Introduction}

The advancement of information technology leads to paradigm shift of organizational behavior and impact to the society especially government organizations. They are investing and implementing a lot of information technology projects to serve the people's needs. This is to push the organization in terms of providing new services and improving processes. However, several projects confront the problem related to information technology investment. For example, the return on investment for each project did not meet the expected outcomes or some parts of the project seems to be similar to other project. This refers to inefficient investment on information technology project. Therefore, some frameworks are needed.

To mitigate the problem, Enterprise Architecture (EA), a blueprint of technology road map and operation plan for organization, is used to achieve organization's goals in terms of information technology investment [1, 2]. It can help organization eliminate unnecessary information technology projects and inconsistent organization's strategies. This is call IT-business alignment. It seems that EA is useful for business which provides the clear goals and missions. However, government organizations may consider the investment on information technology in different aspect, because the goals of government organizations seem to be different from the business. They should concern the benefits of people first. In addition, the process to decide for project investment is also different which is hierarchical process including the decision making process. The environment and ecosystem in information technology and organization's structure is not similar to business as well [3].

Therefore, the specific Enterprise Architecture of government organization is needed to serve the purpose of investment of information technology projects. The influent factors related to Enterprise Architecture framework for government organization should be explored. This is to fulfill the appropriate framework. This research aims to investigate the influent factors and motivation of implementation Enterprise Architecture in government organization.

\section{Backgrounds}

\subsection{Enterprise Architecture}

The conceptual framework to analyze, design and implement the overall of strategic organization's goals is called Enterprise Architecture [4]. The components of the architecture mainly focused on business, information system and technology. These 3 main components should be consistency and reinforcing simultaneously [5]. The role of Enterprise Architecture has become more important since the organization has brought various information systems and used them.

The roles of Enterprise Architecture can be separated into 4 groups they are business planning, strategic planning, implementation and evaluation. The business planning focuses on planning with Enterprise Architecture to obtain the business plan with appropriate information technology usage $[6,7]$. The strategic planning purposes the Enterprise Architecture in terms of supporting and driving core strategies of the organization to achieve the goals [4]. The implementation emphasizes on the process of implementing the information technology into the business process and transformation of old business process to the new one [8]. The evaluation aims to measure and assess the benefit derived from the implemented information technology projects and measure how the project successfully implemented [9].

\subsection{Enterprise Architecture Framework}

The technology-driven organization needs Enterprise Architecture concept to identify goals, missions including information and data used for each work process. Then, the appropriate technologies will be implemented to the organization. The Enterprise Architecture seems to be a blueprint of the organization used for operate all processes to work efficiently. Hence, some Enterprise Architecture frameworks were developed. For example, TOGAF or Zachman frameworks. Most of the frameworks emphasize on the overview of the enterprise. In addition, they are focusing on business view and technology view. Although, the technology architecture is similar to government organization, the business view may not implement with the organization. Thus, the other factors related to government organization needs to be explored.

\section{Research Methodology}

The research conducts the in-depth interview with expert in the area of information technology. The criteria to choose the expert have considered the management level and experience in the area of information technology. In addition, the expert should work or have an experience in government sector. The purposive random was used in this research. 
There were 4 executives and managements which were selected. Two of them are executives in the government organizations, the others have experience in government's information technology projects and audit.

The interview process began with prepared questions related to Enterprise Architecture view for government organization. The questions have been submitted to the experts before the interview. After that, the interview process has begun.

\section{Results}

The results of interviewing the experts can be seen in Table 1 . The results have grouped the question and opinion towards each question in for each expert. The findings can be discussed. The experts seem to have the similar point of views in terms of the difference of government organization and business which refers to goals, budget and regulations. However, the plan to implement Enterprise Architecture is not identified in the near future because there are some threats such as acceptance resistance in the organization which should be aware. In addition, to mitigate the threats, the important things to adapt organization for Enterprise Architecture are education and providing the knowledge to staffs. Moreover, the management is also needed to change the vision. The experts have the mutual opinion in terms of management characteristics. They suggested that the management level for implementing Enterprise Architecture should have a good vision in the information technology and understating the roadmap of the technology matched to organization's objectives.

In addition to indicators of Enterprise Architecture for government organization, the experts also share the experience in terms of performance measure. It appeared that the financial indicators should implement return on investment (ROI) to measure the successful of implemented information technology projects. The changed processes can be measured by the number of workflow reduced in the systems including the time to serve the stakeholder in each process. Importantly, the goals indicator can measure by comparing the plan and actual performance. The expert suggested that the stakeholder satisfaction needs to be surveyed. Moreover, the important stakeholders should be focused on owner and planner.

Table 1. The summary of experts' opinion towards influent factors for implementing Enterprise Architecture in government organization

\begin{tabular}{|c|c|c|c|c|}
\hline \multirow[t]{2}{*}{ Questions } & \multicolumn{4}{|c|}{ Experts } \\
\hline & 1 & 2 & 3 & 4 \\
\hline $\begin{array}{l}\text { The } \\
\text { difference of } \\
\text { government } \\
\text { organization }\end{array}$ & Goals & Goals & $\begin{array}{l}\text { Budget and } \\
\text { regulations }\end{array}$ & $\begin{array}{l}\text { The speed } \\
\text { of decision } \\
\text { making, } \\
\text { regulations } \\
\text { and budget }\end{array}$ \\
\hline $\begin{array}{l}\text { The plan to } \\
\text { implement } \\
\text { EA in the } \\
\text { near future }\end{array}$ & None & None & None & None \\
\hline $\begin{array}{l}\text { The benefits } \\
\text { of EA }\end{array}$ & $\begin{array}{l}\text { See the } \\
\text { overview of } \\
\text { strategic } \\
\text { development }\end{array}$ & $\begin{array}{l}\text { Understating } \\
\text { the IT needs } \\
\text { in } \\
\text { organization }\end{array}$ & $\begin{array}{l}\text { Efficient } \\
\text { problem } \\
\text { solving }\end{array}$ & $\begin{array}{l}\text { See the } \\
\text { overview of } \\
\text { strategic } \\
\text { developme } \\
\text { nt }\end{array}$ \\
\hline Threats & $\begin{array}{l}\text { Acceptance } \\
\text { and } \\
\text { resistance }\end{array}$ & $\begin{array}{l}\text { Communicati } \\
\text { on among } \\
\text { organization }\end{array}$ & $\begin{array}{l}\text { Acceptance } \\
\text { and } \\
\text { resistance }\end{array}$ & $\begin{array}{l}\text { Unclear } \\
\text { organizatio } \\
\text { n strategy }\end{array}$ \\
\hline $\begin{array}{l}\text { Management } \\
\text { characteristi } \\
\text { cs }\end{array}$ & Vision & $\begin{array}{l}\text { Change and } \\
\text { vision }\end{array}$ & Vision & Vision \\
\hline $\begin{array}{l}\text { Influent } \\
\text { factors }\end{array}$ & $\begin{array}{l}\text { Support from } \\
\text { management, } \\
\text { communicati } \\
\text { on }\end{array}$ & $\begin{array}{l}\text { Appropriate } \\
\text { framework }\end{array}$ & $\begin{array}{l}\text { Support } \\
\text { from } \\
\text { manageme } \\
\text { nt, } \\
\text { stakeholder } \\
\text { s }\end{array}$ & $\begin{array}{l}\text { Support } \\
\text { from } \\
\text { manageme } \\
\text { nt }\end{array}$ \\
\hline $\begin{array}{l}\text { Organization } \\
\text { 's adaptation } \\
\text { to EA }\end{array}$ & $\begin{array}{l}\text { Educate staff } \\
\text { and } \\
\text { management }\end{array}$ & Restructure & $\begin{array}{l}\text { Restructure } \\
\text {, cultural } \\
\text { change }\end{array}$ & $\begin{array}{l}\text { Educate } \\
\text { staff and } \\
\text { manageme } \\
\text { nt }\end{array}$ \\
\hline
\end{tabular}

\begin{tabular}{|l|l|l|l|l|}
\hline Indicator & \multicolumn{4}{|l|}{} \\
\hline - Financial & ROI & ROI & $\begin{array}{l}\text { ROI and } \\
\text { budget }\end{array}$ & $\begin{array}{l}\text { ROI and } \\
\text { budget }\end{array}$ \\
\hline - Process & $\begin{array}{l}\text { Number of } \\
\text { reduced } \\
\text { process }\end{array}$ & $\begin{array}{l}\text { Number of } \\
\text { reduced } \\
\text { process, } \\
\text { time }\end{array}$ & $\begin{array}{l}\text { Number of } \\
\text { reduced } \\
\text { process, time }\end{array}$ & $\begin{array}{l}\text { Number of } \\
\text { reduced } \\
\text { process, time }\end{array}$ \\
\hline - Goals & $\begin{array}{l}\text { System } \\
\text { performance }\end{array}$ & $\begin{array}{l}\text { Balanced } \\
\text { Scores } \\
\text { Card }\end{array}$ & $\begin{array}{l}\text { Stakeholder } \\
\text { satisfaction }\end{array}$ & $\begin{array}{l}\text { Stakeholder } \\
\text { satisfaction }\end{array}$ \\
\hline Stakeholder & Owner & Owner & $\begin{array}{l}\text { Owner, } \\
\text { planner, } \\
\text { designer }\end{array}$ & $\begin{array}{l}\text { Owner, } \\
\text { planner }\end{array}$ \\
\hline
\end{tabular}

\section{Conclusions}

Nowadays, the implementation of information technology has been increasing significantly especially government organizations which confront the problem of unplanned and irrelevant information technology projects implementation. So that, the specific Enterprise Architecture factors for government organization is needed and investigated. This research conducts the in-depth interview with experts and executives in the government organizations in order to identify the motivation and related factors to implement Enterprise Architecture for government organization.

The findings of the research can be seen that the government organization has different goals from the business and the management levels needs to adapt themselves for information technology and Enterprise Architecture. The successful implementation of Enterprise Architecture should be supported from management level and communicate through the organization in order to reduce resistance and increase acceptance. Furthermore, the indicators used to measure the success are financial, process and goals. It seems that return on investment (ROI), number of reduced process and stakeholder satisfaction are vital indicators respectively.

In the future, the relationship between factors may be investigated and the sub-criteria of indicators and performance measure should be explored as well.

\section{References}

[1] Federation of EA Professional Organizations. ((2013, Common Perspectives on Enterprise Architecture.

[2] Goel A., Schmidt H., Gilbert D. (2009). Towards formalizing Virtual Enterprise Architecture. IEEE 13th International Enterprise Distributed Object Computing Conference Workshops, 238-242.

[3] Dunlop J. T. (1979). Public Management. Tallahassee, Department of Political Science Florida State University.

[4] Schmidt R., Mohring M., Wibotzki M., Sandkuhl K., Jugel D., Zimmermann A. (2014). Toward a Framework for Enterprise Architecture Analytics.IEEE 18th International Enterprise Distributed Object Computing Conference Workshops and Demonstrations, 266-275.

[5] Khayami R. (2010). Qualitative characteristics of Enterprise Architecture. Procedia Computer Science 3, 1277-1282.

[6] Guoliang L., Xiaohong Y., Xinying Z. (2010). Evaluating Power Grid Enterprise's Investment Returns. Energy Procedia 5, 224-228.

[7] Hoyland C.A. (2012). RQ-Tech, A Strategic-Level Approach for Conceptualizing Enterprise Architectures. Procedia Computer Science 12, $37-42$.

[8] Khayami R. (2010). Qualitative characteristics of Enterprise Architecture. Procedia Computer Science 3, 1277-1282.

[9] Joan Magretta. (2011). Understanding Michael Porter: The Essential Guide to Compettition and Strategy. Harvard Business Review Press, 109110 . 